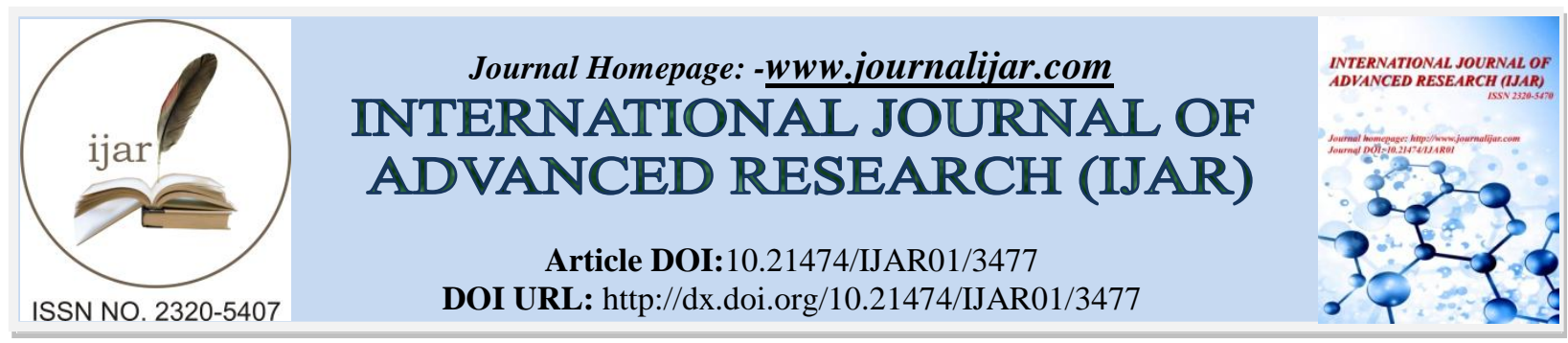

RESEARCH ARTICLE

\title{
PROBLEMS AND PROSPECTSIN SOUTH ASIA; INDO-CHINA'S EFFORTS OF COOPERATION.
}

Mazar Ali Shah, Rahul Kumar and Murtuza Ahmed Barbhuiya.

Phd research scholars, Department of political science A.M.U Aligarh (202002).

\section{Manuscript Info}

Manuscript History

Received: 03 January 2017

Final Accepted: 06 February 2017

Published: March 2017

\begin{abstract}
This paper attempts to analyse the problems and prospects in south Asia by using various indicators based on data from secondary sources. The study reveals that South Asia a land of natural beauty and also known as paradise on Earth, and Switzerland of Asia. But the countries of South Asia are not able to evolve co-operative relations and their relations are characterizing by numerous conflicts. The type and level of conflicts which take place in the sub-continent however vary with changing circumstances, both internal and external, which affect the region. Of late, of course the countries of South Asia realizethe need of cooperation and make some progress in this direction. Indo-china both are the most powerful nations of region performing their role in various direction for maintaining the peace, cooperation and integration in the region.
\end{abstract}

Copy Right, IJAR, 2017,. All rights reserved.

\section{Introduction:-}

The term South Asia is used for the countries lying south of Himalayas and surrounded by the Indian Ocean from three sides. The countries of this region include India, Pakistan, Bangladesh, Sri Lanka, Nepal, Maldives and Bhutan. Apart from Nepal and Bhutan, the rest of the South Asian region has been subject to colonial rule. These countries gained independence in 1947; Pakistan came into existence as a result of partition of India in 1947; Sri Lanka got independence in 1948. Bangladesh emerged as an independent sovereign state after breaking away from Pakistan in 1971. Though the countries differ from each other with regard to climate, race, religion and history, they constitute a single region and possess some common features. Firstly, most of the countries are very poor and majority of their people live below poverty line. Secondly, religion is a predominant factor in these states. In fact, some of the states like Pakistan and Bangladesh were created on religious basis. Thirdly, these countries are faced with problems of unemployment, illiteracy, over population, etc. Fourthly, the countries are agriculturally and industrially backward. However, India is an exception and has made considerable industrial progress. Fifthly, most of the countries are faced with the problem of political instability. Finally, most of the countries (except Pakistan) do not have close military links with super powers. In contrast with the external boundaries of the region, the political geography within the region does not follow any neat pattern. 1 The three most important rivers-Indus, Ganga and Brahmaputra cut across the boundaries of the principal countries in the Indian sub-continent. In spite of differences in physical appearance, complexion, stature and other ethnological features, a common cultural and ethnic outlook unifies the people of the entire region of South Asia. However, the South Asian countries have sharp differences in their perception and approaches on the details of major global and regional issues of peace, security and stability. The pattern of these differences has remained somewhat consistent over a long period except for some occasional minor shift in their strategies. 
South Asia has become an area in which India and China have been seeking to gain political and economic influence over many years. Therefore, it seems appropriate to analyse their relationship with South Asian countries through the lens of the regional power debate. Both countries have claimed regional power status, i.e. a dominant position, and have invested in different ways to shape their respective regions according to their political interests. India has used different bi- and multilateral strategies to pursue its regional leadership role in South Asia. In contrast, China has concentrated on bilateral relations rather than on multilateral structures, in order to expand its traditional regional focus from North East and South East Asia to South Asia ${ }^{1}$.

\section{Conflicts in south asia:-}

The harsh geo-political realities point towards greater potential for conflict rather than peace. These may be well routed in geo-strategic factors and in the strategies of the leading powers of the world to influence these factors in their own interests. Some of the geo-strategic factors are:

Military Stand Off in the Region- Whereas India has tended to find greater convergence in its perceptions with Russian position on many issues; however other South Asian states have reflected towards west towards their world views.

Emergence of China as a Reckonable Power- China's growing power and its assertive approach in dealing with other nations can only create apprehensions and a sense of insecurity in the countries of South Asia excepting those like Pakistan who have sought a quasi-alliance relationship with it. Similarly, China's growing capabilities of power projection could pose a major challenge to peace and security in the days ahead.

Situation in Afghanistan and Middle East- Afghanistan and Middle East are the two conflict areas where local indigenous conflictual factors have been entangled in great power strategies and interests. The continuation or resolution of the conflict in the two areas will have far-reaching influence on the peace and security in the region.

Growth of Extra Regional Military Forces in the Indian Ocean- There has been a massive growth of extra regional military forces in the Indian Ocean in the recent years. The presence of extra regional forces only helps to exacerbate conflictual responses and aggravate the problem of peace and security in the region. Strategically too the Indian Ocean region is important for global nuclear warfare and thus it has become a victim of US and European game plan. The success of US Coalition Strategy to undertake military responses outside NATO areas in conflict situation during the second half of 1987 in Persian Gulf Arabian Sea is noteworthy².

\section{Cooperations:-}

\section{Religious and Cultural Interrelation:-}

South Asian region has uniqueness in shared history, heritage, literature, culture, religion and language. The commonality of culture and religion provides a strong motive for regional cooperation as it has similar lifestyle, fashion and clothing trends, music, food or even cinema. Even the people have family relations across borders that were formed before partition and have sympathy towards them. So this cross-religious, cross-cultural pattern also demands cooperation at regional-level to provide better access and opportunity to people for harmony and religious beliefs. South Asia develops greater economic and political cooperation it is also possible that the notion of panSouth Asian identity will emerge at local and global level and trickle down to the people. That is why AmartyaSen (2006) gives notion of cultural identity where people could have multiple identities.

\section{Economic Acquisitions:-}

In regional cooperation processes trade must be a means not an aim per se to increase the productive power of a state. A long-term economic strategy of any developing state must have diversion in trade destinations including its neighbour destinations, diversity in trade pattern/products including both labour intensive and capital intensive. Most states in this region lack skills, research capacity, financial and technical resources for research and education, in this context establishment of South Asian University and signing of South Asia Free Trade Area agreement (SAFTA) are significant step (Mehta and Kumar 2004; Banik 2006; Ratna and Sidhu 2008; Taneja et al. 2011 ). 2 The share of intra-regional trade is very low in South Asia with comparison to intra Association of Southeast Asian Nations (ASEAN) or intra-EU trade for intraregional trade of SAARC nations; also for SAARC trade with rest of the World. The share of SAARC trade has remained same ranging from 4-6 percent between 2000 and 2013 . This low intra-regional trade has been on account of positive list based approach on exchange of tariff preferences, small product coverage, narrow margins of preferences and inability to address non-tariff barrier ${ }^{3}$. 
political integration, for instance the promotion of democratic values, were only used selectively and remained contingent on India's security concerns vis-à-visthe neighbours. In 2009, the South Asian Association for Regional Cooperation (SAARC) agreed on a Charter of Democracy to strengthen democratic structures in South Asia. The Charter becomes fully operational, it can become an important instrument that allows India to support democratic institutions in neighbouring countries. But it is also an ambivalent instrument because this could be seen as interference in the internal affairs of countries, which India itself rejects. The Indian Technical \& Economic Cooperation Programme (ITEC) has trained many bureaucrats from South Asia and has helped New Delhi to increase its political clout in the region. In 2013-2014 more than 80 per cent of India's total loan and aid budget was allocated to its South Asian neighbours, especially Bhutan, Bangladesh, and Afghanistan.

\section{India's efforts}

INDIA seems to be a regional power in South Asia by default. Governments in New Delhi have used a variety of instruments to further their interests in the region: wars have India been fought and won (for instance with Pakistan); militant groups have been supported in their fight against authoritative regimes (East Pakistan) and democratic governments (Sri Lanka); trade sanctions and border blockades have been imposed; secret arrangements have been negotiated (Nepal); unilateral economic and political concessions (SAARC) have been made; development aid has been provided (Afghanistan, Bhutan, Nepal); and successful (Nepal) and unsuccessful (Sri Lanka) attempts for mediation in civil wars have been made

Since its independence in 1947, India has been perceived as a regional power or hegemon in South Asia. Due to the asymmetry of its territorial and demographic size, its military dominance, and its economic potential, India seems to be a regional power by default. But a closer look reveals that India's superior economic and military resources have hardly resulted in the achievement of its foreign policy goals.

For many years, India perceived its neighbouring countries as a major part of its national security and its strategic sphere of influence. India's policy vis-à-vis the Himalayan states has always been determined by its relations with China and it has always aimed to reduce China's influence on its northern border. The friendship agreements with the Himalaya kingdoms Bhutan (1949), Sikkim (1950), and Nepal (1950) gave India a great involvement in the internal affairs of its neighbours. Prime Minister Jawaharlal Nehru, who is often blamed for being an 'idealist' in international affairs, appears to have had a much more 'realistic' perspective with regard to India's neighbours in the Himalayas ${ }^{4}$.

Indira Gandhi's South Asia doctrine saw the region as part of India's national security. This became the basis for various political and military interventions during the 1970s and 1980s. But many of the interventions did not bring about the desired long-term results for India. The military victory over Pakistan in 1971 was not followed by a permanent solution of the Kashmir issue. India supported Bangladesh after its independence in 1971 but could not prevent Bangladesh's economic and political realignment after the military coup in 1975. India's attempts to mediate in the Sri Lankan civil war in the late 1980s ended in political and military disaster.

After the economic liberalisation in 1991, economic issues became more and more important for India's foreign policy at both the regional and the global levels. In the mid-1990s, the Gujral doctrine highlighted the concept of non-reciprocity: India was now willing to make unilateral, political, and economic concessions to weaker states. South Asia was no longer seen as a part of India's national security, but as part of its economic development. The new focus on economics gained more importance vis-à-vis the traditional security concerns. Prime Minister Manmohan Singh moved economic relations to the centre of India's foreign policy, promoted economic development, gave greater importance to India's relations with the great powers, and tried to establish friendly relations with the neighbouring countries.

\section{China's efforts:-}

China's relations with India and South Asia have also undergone several changes. The good relationship it had with India in the 1950s was overshadowed by the boundary dispute. After the border war in 1962, China deepened its relations with Pakistan. As part of its ideological foreign policy, China supported various militant movements in South Asia, as for instance rebel groups in India's northeast. 
China's strong economic and military support for Pakistan since the 1960s and its later efforts to develop its economic relations with India's neighbours have always raised apprehensions in India, that China's South Asia policy was aimed at pressuring India.Following its economic liberalisation in the late 1970s, China has also shifted

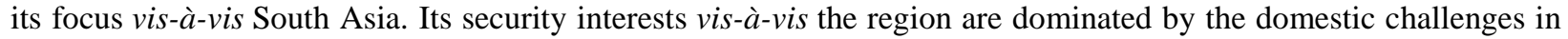
Xinjiang and Tibet. China's South Asia policy has been characterised as 'multi-layered and complicated and not necessarily compatible and complementary'. China's attempts to create new access to the Indian Ocean as part of its 'One Belt, One Road' (OBOR) initiative by building land corridors through Pakistan and Bangladesh will increase the strategic importance of South Asia in the long-term.

In the field of security, China has the upper hand with regard to military hardware and strategic investment, whereas India has stronger military-to-military relations with its neighbours. In 2011, India's National Security Advisor Shiv Shankar Menon pointed out that India has to expand its role as security provider for South Asia as well as for the Indian Ocean region in order to counter the growing Chinese influence 5 . Prime Minister Modi also emphasised this point during his various visits to the SAARC countries and the island states of the Indian Ocean in spring $2015^{4}$.

\section{Conclusion:-}

It seem that despite its superior material resources, India has hardly ever managed to establish itself as regional power in the long-term perspective. Nehru's and Indira Gandhi's attempts to portray the region as part of India's national security and to secure the country's foreign political interests through military, economic, and political interventions have proven counterproductive in two ways. First, the process of nation-building in the neighbouring countries prevented a close approximation with India. Because of common religious, linguistic, and ethnic ties, nation-building was about delimitation of the dominant neighbour. Second, all neighbours have used the strategy of internationalising their bilateral disputes with India, sometimes more and sometimes less successfully. Pakistan is the most obvious case, but Bangladesh, Nepal, and Sri Lanka have also played the 'China card' at various times. Since its liberalisation in 1991, India has put its South Asia policy on a new basis with the Gujral and the Manmohan doctrines. South Asia is regarded more as a market that can contribute to India's economic development and therefore the focus of bilateral and multilateral initiatives is on regional public goods, like better connectivity as well as on unilateral economic concessions, in order to expand intra-regional trade.

In contrast to India, China enjoys a comfortable position. Politically, China is regarded as a 'neutral' player in South Asia. China has never been part of the discourse on nation-building and its relations with the region are not marred by the baggage of history. Economically, China is a more attractive trade and investment partner for South Asian countries. In the field of security, China is an important partner for the acquisition of military hardware. However, India has also improved its security collaboration with many South Asian countries in recent years.

India seems to be caught in a catch-22 situation in South Asia. On the one hand, religious, linguistic, and ethnic ties bind India with the region. On the other hand, those ties do separate India from its neighbours with regard to nationbuilding. Hence, India will scarcely be able to overcome its resentments in the neighbouring countries and to counter the advantages that China enjoys in South Asia with regard to politics, economics, and security. However, China's growing influence in South Asia does not imply a claim for any regional power status. It pursues its national interests and does not seem to be interested in providing regional public goods. It remains arguable whether China's activities within the region serve its own economic development, or how far it pursues a policy of 'encirclement' against India. It should not be overlooked that India and China are also cooperating in joint regional initiatives like the Bangladesh-China-India-Myanmar and that China has also promised to make large-scale infrastructure investment in India. Despite its disadvantageous position, India should continue its efforts to provide regional public goods through both bilateral and multilateral initiatives. This will foster regional cooperation in South Asia, so that the question of 'who is the regional power' may even become superfluous in the long time 


\section{Bibliography:-}

1. J. Mohan Malik, 'South Asia in China's Foreign Relations', Pacifica Review: Peace, Security \& Global Change, 13(1), 2001, pp. 73-90.

2. Inder Kumar Gujral, A Foreign Policy for India, Ministry of External Affairs, New Delhi, 1998.

3. Mohan Guruswamy, ZorawarDaulet Singh, India China Relations: The Border Issue and Beyond, Viva Books, New Delhi, 2009; S. D. Muni, Tan Tai Yong (eds.), A Resurgent China: South Asian Perspectives, Routledge, New Delhi, 2012;

4. Prakash Chandra and PremArora, Comparative Politics and International Relations, p. 96 5.Dr. Hari Saran, 'Growing Chinese Influence in Indian Ocean RIM Region, Indian Journal of Strategic Studies 1., VoIXXVIII,

5. Madhur Anand, 'Growing Importance of the Indian Ocean In Post- Cold war Era and its Implications .

6. Dr.Hari Saran, 'Growing Chinese Influence in Indian Ocean RIM Region'. Indian Journal of Strategic Studies, VolXXVIII, p136

7. Zhang Li, 'To Manage Conflict in South Asia: China's Stakes. Perceptions and Inputs', Institute for Security \&Development Policy, Asia Paper, October 2009, p. 10s 